\title{
Kajian Feminis Dalam Novel Perempuan Terpasung: Gejolak Cinta di Balik Cadar Karya Hani Nagshbandi
}

\author{
Mega Situmorang ${ }^{1}$, Megawaty Indah Qemala ${ }^{2}$, Iga Yana Tarigan ${ }^{3}$, Veronica \\ Febriana $S^{4}$ \\ E-mail: megasitumorang98@gmail.com ${ }^{1}$, megawatyindahqemala0907@gmail.com², \\ igatarigan05@gmail.com ${ }^{3}$, veronica.silalahi1998@gmail.com ${ }^{4}$ \\ Universitas Prima Indonesia
}

\begin{abstract}
ABSTRAK
Penelitian ini bertujuan untuk mendeskripsikan karakteristik tokoh feminis, kedudukan, peran perempuan dalam novel, masalah-masalah sosial yang dihadapai perempuan dalam novel, maksud pengarang perempuan dalam novel dan mendeskripsikan nilai-nilai yang terdapat dalam novel Perempuan Terpasung: Gejolak Cinta di Balik Cadar karya Hani Naqshbandi. Desain penelitian kualitatif deskriptif dan obyek penelitian sekaligus sumber data ialah karakteristik tokoh feminis, kedudukan atau peran perempuan, masalah-masalah sosial yang dihadapi perempuan, maksud pengarang perempuan, dan nilai-nilai yang terdapat dalam novel. Teknik pengumpulan data yaitu membaca secara cermat, memahami isinya secara keseluruhan, menganalisis data; dengan mengidentifikasi bagian-bagian yang berkenaan dengan kajian feminism. Instrumen kunci dalam penelitian ini ialah peneliti dan pedoman analisis teks dan analisis data menggunakan model miles and Huberman dengan tahapan, reduksi data, penyajian data dan penarikan kesimpulan. Keabsahan data dilakukan dengan cara triangulasi, pemeriksaan teman sejawat, analisis kasus negatif dan proses auditing. Hasil penelitian yang ditemukan ialah karakteristik tokoh perempuan yaitu sabar, baik hati, penyendiri, penurut, pemberontak, dan bijaksana. Kedudukan, peran dan fungsi perempuan ialah seorang isteri bagi suami dan ibu bagi anak-anak, anak terakhir dalam keluarga, penulis di surat kabar. Permasalahan tokoh perempuan ialah permasalahan tradisi/budaya, pernikahan dini dan masalah pasangan hidup. Pengarang perempuan atas novel bermaksud menampilkan permasalahan yang mayoritas dialami oleh seтua perempuan yakni penderitaan karena tindakan suami/laki-laki yang kurang menghormati perempuan. Nilai-nilai yang dalam novel ialah nilai agama, moral, pengajaran dan nilai keluarga. Peneliti menyarankan adanya kesadaran anggota masyarakat untuk memperjuangkan hak dan peran perempuan dalam kehidupan sosial.
\end{abstract}

Kata Kunci: Kajian, Feminis, Novel Perempuan Terpasung

\section{PENDAHULUAN}

Karya sastra merupakan hasil karya manusia dengan mendayungkan imajinasi yang terdapat dalam diri pengarangnya. Keberadaan karya sastra dalam kehidupan manusia dapat mengisi " kebahagiaan jiwa" karena membaca karya sastra bukan saja 
memberikan hiburan melainkan pula memberikan pencerahan jiwa. Dengan kata lain, karya sastra dapat memberikan hiburan dan manfaat (Elvi, 2019:94). Karya sastra tidak dapat dilepaskan dari pengarang dan kehidupan manusia sebagai produk kelahiran karya sastra. Sastra bukan sekedar dari kekosongan sosial melainkan hasil racikan perenungan dan pengalaman sastrawan dalam menghadapi problema dan nilai-nilai tentang hidup dan kehidupan (manusia dan kehidupan). Karya Sastra dibagi menjadi tiga jenis yaitu prosa fiksi, puisi dan drama. Prosa fiksi juga dibedakan menjadi beberapa jenis dalam berbagai bentuk seperti roman, novel, novelette, maupun cerpen. Istilah prosa fiksi atau cukup disebut karya fiksi, biasa juga diistilahkan dengan prosa cerita, prosa narasi, narasi atau cerita berplot (Dani, 2019:12).

Karya sastra seperti novel adalah salah satu bentuk karya fiksi yang menyampaikan permasalahan kehidupan yang kompleks. Hal ini dimungkinkan karena persoalan yang dibicarakan dalam novel adalah persoalan tentang manusia dan kemanusiaan. Perkembangan novel di Indonesia cukup pesat. Hal ini terbukti dengan banyaknya novel-novel baru yang diterbitkan. Novel-novel tersebut mempunyai bermacam tema dan isi, antara lain tentang masalah-masalah sosial yang pada umumnya terjadi dalam masyarakat (Yuningsih, 2015:2)

Salah satu kajian dalam karya sastra, Novel ialah kajian feminisme. Feminisme lahir pada abad ke-20. Jadi tujuan feminisme ini adalah keseimbangan, interelasi gender. Feminisme adalah studi sastra yang terfokus pada analisis terhadap wanita. Dalam kritik sastra feminisme bukan berarti mengkritik seorang wanita akan tetapi ada arti sederhana yang terkandung didalamnya mengkritik sastra harus dengan kesadaran khusus bahwa ada jenis kelamin yang sangat berhubungan dengan budaya, sastra, dan sebuah kehidupan. Feminisme merupakan kesadaran terhadap ketidakadilan gender yang menimpa kaum perempuan, baik dalam keluarga maupun dalam masyarakat. Feminisme sebagai jembatan untuk menuntut persamaan hak antara perempuan terhadap laki-laki (Tia Ratna Zuraida, 2013:3))

Sebagaimana dikembangkan kaum feminis, kajian gender dalam karya sastra mengarahkan perspektifnya pada beberapa tujuan, yang diantaranya dapat diacu sebagai cara kreatif untuk membebaskan perempuan dalam menulis dan menceritakan pengalamannya sendiri diluar konvensi, aturan, konsep dan premis budaya patriarkis. 
Wacana gender juga berusaha menciptakan androginitas budaya, membangun kesetaraan tatanan sosial yang didasarkan pada nilai-nilai keperempuanan (Yenni Hayati, 2012:85). Oleh karena itu, dalam analisis dalam kajian feminisme hendaknya mampu mengungkapkan aspek-aspek penindasan wanita atas diri kaum pria. Sebab, Isu feminisme selalu dikaitkan dengan persamaan hak dan kesetaraan gender.

Berkat kaum usaha feminis dalam mengkaji karya sastra, eksistensi perempuan dan karyanya mulai dipertimbangkan dengan adil. Hal serupa juga menampak dalam perkembangan sejarah sastra di Indonesia (Aning Ayu, 2013:116). Dalam sastra (Jawa) kuno, terutama dalam wiracarita dan kakawin tampak jelas bahwa pencitraan perempuan cenderung sebagai sosok pujaan. Karya sastra muncul sebagai bentuk refleksi dari kehidupan masyarakat dan kejadian-kejadian ataupun fenomena yang terjadi di alam semesta ini. Sastra sebagai bentuk refleksi kehidupan tentunya di dalamnya mengandung nilai-nilai. Teori feminis mencoba memberikan jalan tengah, untuk mengemukakan keseimbangan agar kedua pihak memperoleh makna yang sesuai dengan kondisinya dalam masyarakat. Feminisme pascamodern memandang bahwa baik laki-laki maupun perempuan sekaligus sebagai pusat dan nonpusat, disesuaikan dengan posisi kondisinya dalam masyarakat. Kaum perempuan tidak menuntut persamaan biologis sebab perbedaan tersebut merupakan hakikat (Nyoman Kutha, 2004:188). Dengan kata lain, kajian feminis berusaha untuk mengangkat derajat perempuan.

Fenomena atau permasalahan yang kerap kali terjadi dalam narasi kajian feminism dalam karya sastra adalah posisi kaum perempua. Dunia sastra Indonesia menerbikan banyak novel dengan pengarang pria, tetapi tidak mencerminkan atau mengemukakan gagasan sesuai dengan perjuangan pergerakan feminisme. Tokoh Wanita dalam cerita dihadirkan sebagai makhluk yang menyimpan kelembutan, selalu mengalah atau tersubordinasi oleh kekuasaan laki-laki, menjadi korban atas perilaku kaum pria dan atas pengaruh eksistensi budaya maupun sosial. Kebanyakan pengarang pria mendudukan wanita sebagai objek yang tidak mampu melawan kemapanan budaya, seperti budaya patriarki dan feodalisme pada masyarakat (Bambang, 2011:237). Oleh karena itu, salah satu tujuan dari pengangkatan tema feminisme adalah ingin menyamakan kedudukan perempuan dengan laki-laki. 
Selain itu, permasalahan umum bersifat real ialah 1) masih berlakunya budaya patriarkat, sehingga kedudukan laki-laki dipandang selalu lebih tinggi dibandingkan perempuan. 2) Di dalam budaya patriarkat nilai-nilai perempuan sebagai sosok lemah dan memerlukan perlindungan laki-laki bukan untuk membuatnya kuat seraya menghadapi ketidakpastian hidup. Padahal, Pengarang-pengarang perempuan bahkan para feminis tidak ingin hal itu terjadi terus menerus, karena hal itu sama halnya pengekangan terhadap perempuann. Tema feminisme memang sepantasnya diangkat karena para perempuan memiliki kebebasan personal is political dan tidak ingin di pandang dari segi seksisme saja. Apabila dilihat dari sisi kesusastraan, 3) karya sastra kerap kali menunjukkan hegemoni laki-laki terhadap perempuan dan bahwa perempuan adalah objek erotik laki-laki. Dalam sebuah karya sastra yang tertulis oleh laki-laki, dimana 4) perempuan sebagai tokohnya selalu dieksploitasi. Segala hal yang menarik dari perempuan akan digunakan sebagai daya tarik karya tersebut. Hal ini menunjukkan bahwa 5) perempuan adalah makhluk kedua, setelah laki-laki. Bagi para feminisme, hal tersebut sangat menyakitkan. Oleh karena itu, perlu dilakukan pembelaan-pembelaan Kaum perempuan dalam karya sastra melalui kritik ataupun kajian sastra (Indrya Mulyaningsih, 2015:109).

Salah satu novel yang akan dikaji ialah novel Perempuan Terpasung: Gejolak Cinta di Balik Cadar karya Hani Naqshabandi. Lewat novel terdapat dua hal utama yang menjadi sorotan, yakni (1) memperjuangkan persamaan derajat perempuan dengan lakilaki, dan (2) memperjuangkan otonomi perempuan untuk menentukan apa yang baik bagi dirinya. Oleh karena itu rumusan masalah penelitian ialah 1) Bagaimana kajian karakteristik tokoh feminis dalam novel Perempuan Terpasung: Gejolak Cinta di Balik Cadar karya Hani Naqshbandi? 2) Bagaimana posisi, kedudukan atau peran perempuan dalam novel Perempuan Terpasung: Gejolak Cinta di Balik Cadar karya Hani Naqshbandi? 3) Bagaimana masalah-masalah sosial yang dihadapai perempuan dalam novel Perempuan Terpasung: Gejolak Cinta di Balik Cadar karya Hani Naqshbandi? 4) Bagaimana maksud pengarang perempuan dalam novel Perempuan Terpasung: Gejolak Cinta di Balik Cadar karya Hani Naqshbandi? 5) Apa saja nilai-nilai yang terdapat dalam novel Perempuan Terpasung: Gejolak Cinta di Balik Cadar karya Hani Naqshbandi?. Sedangkan tujuan penelitian ialah 1) mendeskripsikan karakteristik tokoh feminis dalam novel Perempuan Terpasung: Gejolak Cinta di Balik Cadar karya Hani 
Naqshbandi? 2) mendeskripsika kedudukan, peran perempuan dalam novel Perempuan Terpasung: Gejolak Cinta di Balik Cadar karya Hani Naqshbandi? 3) Mendeskripsikan masalah-masalah sosial yang dihadapai perempuan dalam novel Perempuan Terpasung: Gejolak Cinta di Balik Cadar karya Hani Naqshbandi? 4) mendeskripsikan maksud pengarang perempuan dalam novel Perempuan Terpasung: Gejolak Cinta di Balik Cadar karya Hani Naqshbandi? 5) mendeskripsikan nilai-nilai yang terdapat dalam novel Perempuan Terpasung: Gejolak Cinta di Balik Cadar karya Hani Naqshbandi?

Hasil yang diharapkan dari penelitian ini ialah 1) Adanya karakteristik tokoh perempuan yang ideal dalam karya sastra novel, 2) Adanya kesetaraan kedudukan, fungsi dan peran antara laki-laki dan perempuan dalam masyarakat, 3) Adanya penyelesaian atau solusi atas masalah-masalah sosial yang dihadapi oleh kaum peremuan, 4) Eksplisitya setiap maksud pengarang feminis dalam Novel sehingga dapat dijadikan dasar rujukan dalam hidup dan kehidupan, 5) Adanya nilai-nilai yang terkandung yang dapat diteladani pada tokoh feminis dalam setiap karya sastra.

Berdasarkan uraian di atas peneliti melakukan penelitian tentang Kajian Feminisme dalam Novel Perempuan Terpasung karya Hani Naqshbandi.

\section{METODE PENELITIAN}

Penelitian ini menggunakan desain penelitian kualitatif deskriptif. Bodgan dan Taylor dalam Moloeng (2010:4) mendefinisikan penelitian kualitatif sebagai prosedur penelitian yang menghasilkan data deskriptif berupa kata-kata tertulis dan bukan menguraikan dengan cara angka-angka dan juga tidak menggunakan rumus (Moloeng (2007:11). Penelitian ini tergolong penelitian jenis kualitatif. Alasannya ialah peneliti bekerja langsung untuk mengumpulkan data-data yang dikumpulkan sesuai tujuan penelitian yang ditetapkan. Penelitian tentang Kajian Feminisme dalam Novel Perempuan Terpasung: Gejolak Cinta di Balik Cadar karya Hani Naqshbandi dilaksanakan pada tahun 2020. Obyek Penelitian, sekaligus sumber data ialah karakteristik tokoh feminis, kedudukan atau peran perempuan, masalah-masalah sosial yang dihadapi perempuan, maksud pengarang perempuan, dan nilai-nilai yang terdapat dalam novel. Peneliti menggunakan teknik pengumpulan data dalam penelitian ini, yaitu: membaca secara cermat, memahami isinya secara keseluruhan, menganalisis data; 
dengan mengidentifikasi bagian-bagian yang berkenaan dengan kajian feminisme novel, dan kaitan lain sesuai judul penelitian. Instrumen kunci dalam penelitian ini ialah peneliti sendiri sebab peneliti mereduksi bagian-bagian penting, mendisplay data dan menyimpulkan data berdasarkan data yang sudah dianalisis. Instrumen penelitian yang dikhususkan untuk mengambil data yakni berupa pedoman analisis teks dalam Perempuan Terpasung: Gejolak Cinta di Balik Cadar karya, yang didasarkan atas obyek-obyek penelitian. Penelitian ini menggunakan teknik analisis data model miles and Huberman dengan tahapan, 1) Reduksi Data, yakni merangkum, memilih hal-hal yang pokok, memfokuskan pada hal-hal penting, mencari pola dan membuang data yang tidak diperlukan. 2) Penyajian Data, Peneliti akan menyajikan data secara deskriptif tentang obyek penelitian yakni karakteristik tokoh feminis, kedudukan atau peran perempuan, masalah-masalah sosial yang dihadapi perempuan, maksud pengarang perempuan, dan nilai-nilai yang terdapat dalam novel Perempuan Terpasung: Gejolak Cinta di Balik Cadar karya, karya Hani Naqshbandi. Peneliti menyajikan data secara kualitatif yakni menguraikannya dalam teks yang bersifat naratif (menjelaskan). 3) Penarikan Kesimpulan, yakni peneliti akan melakukan penarikan kesimpulan dan verifikasi atas temuan yang sudah diperoleh berdasarkan hasil analisis data. Untuk menetapkan keabsahan (trustworthiness) data diperlukan teknik pemeriksanaan (Lexy J. Moleong, 2009:326-342), yaitu dengan kriteria-kriteria triangulasi, pemeriksaan teman sejawat, analisis kasus negatif dan proses auditing.

\section{HASIL PENELITIAN DAN PEMBAHASAN}

Hasil penelitian mendeskripsikan tentang kajian feminis novel Perempuan Terpasung: Gejolak Cinta di Balik Cadar karya Hani Naqshbandi antara lain karakteristik tokoh utama perempuan, kedudukan, peran dan fungsi perempuan, permasalahan sosial yang dialami perempuan, maksud pengarang perempuan dan nilainilai yang terkandung dalam novel. Hasil-hasil penelitian dipaparka berikut ini.

\section{Karakteristik Tokoh Perempuan pada Novel Perempuan Terpasung: Gejolak Cinta di Balik Cadar, Karya Hani Naqshbandi}


Karakteristik Tokoh Perempuan dalam Novel Perempuan Terpasung: Gejolak Cinta di Balik Cadar yakni 1) Sabar. Sarah setiap hari mengalami kesendiriannya yang hanya menjadi seorang isteri dan ibu bagi anak-anaknya tanpa dibantu oleh siapapun. Ia dengan sabar melakukan semua pekerjaannya sebagai isteri dan ibu bagi anak-anaknya tanpa dibantu oleh suaminya. Karena suami dianggap lebih tinggi kedudukannya daripada perempuan sehingga tidak mengerjakan pekerjaan rumah. Padahal kedudukan, peran dan fungsi perempuan seyogianya sederajat, yang berbeda hanya segi biologis yakni jenis kelamin, perempuan hamil dan melahirkan. Semua pekerjaan dan tugas semestinya dapat dilakukan oleh laki-laki dan perempuan. Walupun demikian Sarah tetap sabar dan berusaha bersama hidup dengan anak-anaknya. Kesabaran Sarah ditampilkan dalam teks: "Sejak lama, Sejak malam pertama pernikahannya, Sarah menyadari bahwa Kebahagiannya telah tergadaikan oleh sesuatu yang ia pilih, ia selalu berusaha melupakan kenangan itu. Berusaha melupakan perasaan tersiksa oleh kesendirian menjadi seorang istri dan ibu tanpa bantuan seorang pun" Hani Naqshabandi (2010:9). 2) Baik hati, Sarah. seorang perempuan yang memiliki karakter baik hati. Ia membelikan hadiah dan memberikannya kepada pembantu yang ada di rumahnya. Sarah memberikan perhatian kepada orang lain dan respek kepada orangorang yang ada di sekitarnya. Sarah melakukan inisiatif ini: "Sesampai di rumah, Sarah langsung menuju kamar anak kembarnya. Mereka telah terlelap setelah puas bermain. Sarah memanggil sang pembantu kemudian memberikan hadiah yang telah ia beli untuknya" Hani Naqshabandi (2010:17). 3) Penyendiri. Sarah adalah seorang perempuan yang ada dalam situasi kesendirian karena yang dia perankan hanyalah pekerjaan isteri dan pekerjaan ibu bagi anak-anaknya. Namun, dalam kesendiriannya, Sarah adalah seorang perempuan yang suka menulis. Ia menulis pengalamannya dalam buku harian bahkan melakukan korespondensi kepada salah satu redaksi di surat kabar. Ia menuliskan situasi-situasi perempuan di daerahnya yang kerap kali dijadikan sebagai korban ketidakadilan gender bahkan dirasakannya bahwa keberadaan perempuan menurutnya adalah kesalahan biologis. Sarah menulis: "Kesendirian adalah satusatunya hal yang bisa membuat kita merasa bahwa keberadaan kita adalah kesalahan biologis. Hal itu ia tulis di dalam catatan hariannya suatu hari. Hani Naqshabandi( 2010:24). Idealnya, keberadaan perempuan itu tidaklah salah secara biologis yang salah ialah perlakuan yang ditindaki kepada perempuan sebagai kelas dua. 4) Penurut. Sarah 
adalah seorang perempuan yang mengikuti tradisi-tradisi dalam keluarganya termasuk tradisi peran perempuan yang hanya bereperan dan berkedudukan sebagai ibu rumah tangga. Karena laki-laki adalah prioritas baik dalam keluarga dan maupun kehidupan sosial; "Sarah selalu mengatakan kepada ibunya, sungguh semua ini hanya tradisi, ibu. Tradisi yang berdiri di atas garis pembatas dan tidak pernah ikut pergi bersama kita ( 2010: 11). Tradisi yang dimaksud yang dialami Sarah ialah bahwa perempuan hanya bisa bungkam dari situasinya, menghadapi sendiri berbagai masalah, misalnya pernikahan paksaan, perselingkuhan suami dengan perempuan lain dan kesewenangan laki-laki atas perempuan. Perempuan tidak memiliki kesempatan untuk membela diri. Mereka hanya sebagai korban atas ketidak adilan dan tradisi yang tak bisa diubah dimana laki-laki memiliki kuasa tinggi atas diri perempuan. 5) Pemberontak. Sarah melakukan pemberontakan terhadap tradisi tentang penutup wajahnya atau cadarnya. Sebab, kehidupan keluarganya tidaklah hidup sesuai dengan aturan agama yang ideal terkait pemakaian cadar. Sarah sering melakukan pemberontakan karena tampilan fisik religius tidaklah sesuai dengan keberadaan dan perlakuan yang dia terima dari suaminya, dimana dirinya terpasung dalam tradisi perempuan yang tidak bisa menyampaikan keinginan-kenginannya dan juga tidak mampu melakukan pembelaanpembelaan terhadap penderitaan yang dialaminya. Novel menceritakan;"Pemberontakannya yang terakhir ditujukan pada penutup wajahnya. Ini bukan pemberontakan yang berbahaya, tapi terjadi berkali - kali. Ia selalu menyampaikan pemberontakan ini kepada keluaganya, dan sekali kepada suaminya. Hani Naqshabandi ( 2010: 1). Namun, pemberontakannya ini tidaklah berhasil sehingga dia dan perempuan-perempuan lain memiliki nasib yang sama yakni terpasung dan terkekang karena menjadi korban laki-laki yang dianggap lebih tinggi derajatnya dan sesuka hati. 6) Bijaksana. Sarah adalah perempuan yang bijaksana ia bukanlah seorang yang suka melakukan penindasan dalam segala hal. Walaupun dia adalah seorang perempuan yang terpasung, namun Sarah adalah perempuan yang kuat atas situasi yang dialaminya sekalipun dia menjadi korban tradisi dan perlakuan jelek dari suaminya. Situasi sarah dijelaskan: "Sarah teringat pada sebuah buku yang pernah dibacanya yang mengatakan bahwa warna merah mencerminkan kepribadianyang kuat. Dan ia ingin menjadi perempuan yang kuat, tapi tidak menindas. Hani Naqshabandi ( 2010 : 18). Sarah bahkan memperhatikan orang disekitarnya seperti memberikan hadiah 
kepada pembantu di rumahnya. 7) Pemberani. Sebenarnya Sarah, adalah perempuan pemberani dan seorang cerdas. Ia mampu secara intelek untuk membedakan kehidupan yang dialaminya terkait tradisi dan posisinya dalam lingkup keluarganya. Hanya karena terpasung oleh tradisinya itulah yang membuat Sarah tidak bisa berbuat apa-apa. Ia seakan melawan budayanya sendiri. Sarah bergumam: "Andai Sarah wanita Eropa, mereka tidak akan bersikap kasar! Sarah tidak memperdulikan Polisi agama itu. Tibatiba ia merasa ujung tongkat telah menyentuh tubuhnya. Sarah geram dan memutar tubuh untuk mengucapkan kata-kata kemarahan. Hani Naqshabandi (2010:12 ). Sebenarnya, jelas bahwa perempuan memiliki keberanian, namun kesempatan untuk mengekspresikan diri dan karena terikat oleh budaya yang memasung maka perempuan tidak bisa berkembang.

\section{Kedudukan, Peran, Fungsi Perempuan pada Novel Perempuan Terpasung: Gejolak Cinta di Balik Cadar, Karya Hani Naqshbandi}

Kedudukan, peran dan fungsi perempuan dalam novel Perempuan Terpasung: Gejolak Cinta di Balik Cadar adalah tokoh perempuan yang bernama Sarah ialah 1) Isteri da Ibu, Sarah adalah seorang isteri bagi suaminya, Khalid dan Ibu bagi kedua anaknya yang kembar. Sarah tidak memiliki peran selain itu, sebab dirinya terpasung oleh tradisi wanita yang hanya mampu berperan sebagai isteri dan ibu saja dalam keluarga. Walaupun sebenarnya, Sarah adalah wanita yang cerdas yang terbukti rajin menulis surat di salah satu surat kabar yang dipimpin oleh Hisyam yang juga sebenarnya memiliki perilaku yang tidak baik bagi perempuan. Sekalipun tulisan-tulisan Hisyam banyak membela kaum perempuan. Narasi Novel menceriterakan tentang Sarah, “ Ia berusaha melupakan perasaan tersiksa oleh kesendirian menjadi seorang istri dan ibu tanpa bantuan seseorang pun. Tak ada yang dapat memahami apa yang diinginkan seorang wanita dalam masyarakat." Hani naqshabandi (2010:08). Teks ini memperjelas bahwa Perempuan hanya sebagai Ibu dan Isteri saja, walaupun keinginankeinginan perempuan itu banyak dan sangat jarang dipahami dalam masyarakat. Perempuan menjadi terpasung dalam budaya yang dianggap perempuan tidak mampu berperan lebih. 2) Sarah adalah seorang Anak dari keluarga yang memiliki kakak/saudara laki-laki. Ia bertanya dan berdebat soal penggunaan penutup muka, yang mana penutup muka boleh dibuka ketika ia keluar dari Saudi. Ia melakukan konfrontasi 
dan menilai tradisi pemakaian cadar yang tidak konsisten sebagai penyalahgunaan aturan dalam agama. Sarah mengatakan, " Mengapa mereka membolehkanku membuka penutup wajah ketika aku pergi keluar Saudi dimana mata-mata asing dapat memandangku?" Tanya sarah kepada ibunya ketika perdebatan di rumah semakin keras antara sarah dan kakak-kakak lelakinya yang berjenggot." Hani naqshabandi (2010:11). Sarah menyadari bahwa aturan yang dianut oleh keluarganya dan suaminya tidak berhubungan dengan prinsip agama atau Syariat, entah itu soal penutup wajah atau lainnya. Sarah mulai menyadari bahwa keluarganya sangat dipengaruhi oleh opini masyarakat. 3) Penulis, Sarah boleh kita katakan sebagai seorang penulis, dia sering mengirim tulisannya di surat Kabar di London. Walaupun isi tulisannya kebanyakan tentang penderitaannya dan yang dialami perempuan di Saudi yang kerap menjadi "sandera" para suami yang atas nama tafsir agama, merasa berhak melakukan apa saja, menyakiti, meninggalkan, atau malah melakukan pelecehan seksual terhadap para pembantu rumah tangga. Teks novel mempertegas permasalahan ini: " Mata sarah tertuju lagi pada sebuah baris dari paparan majalah tersebut yang membuatnya sangat marah. Baris penutup itu menyatakan," penghianatan keluarga sebenarnya bukanlah kebiasaan masyarakat muslim, yaitu masyarakat Arab Saudi yang berpegang teguh pada keyakinannya." Hani naqshabandi (2010:30).

\section{Permasalahan Sosial Perempuan pada Novel Perempuan Terpasung: Gejolak Cinta di Balik Cadar, Karya Hani Naqshbandi}

Permasalahan sosial yang dialami oleh tokoh perempuan dalam Novel Perempuan Terpasung: Gejolak Cinta di Balik Cadar ialah 1) Masalah Tradisi/Budaya, Sarah yang hidup dalam tradisi terpasung dimana perempuan hanya sebagai obyek penikmatan para lelaki saja dan diperlakukan sewenang-wenang oleh suami. Tradisi seperti ini diceriterakan dalam Novel; "Tak ada yang dapat memahami apa yang diinginkan seorang wanita dalam masyarakat. Para lelaki adalah orangorang yang bertuhan, sedangkan para wanita adalah mayat-mayat yang siap untuk ditinggalkan”Hani Naqshabandi (2010:9). Begitu mudahnya laki-laki meninggalkan perempuannya dan mencari yang lain, sekalipun hidup dalam agama. Sarah, wanita muslim dari Arab Saudi, istri dari seorang Khalid dan juga merupakan ibu dari dua orang anak. Ia hidup dalam kungkungan tradisi kolot yang berkedokkan agama. Selain 
itu, tradisi pemakaian cadar dimana aturan yang dianut oleh keluarganya dan suaminya tidak berhubungan dengan prinsip agama dan syariat, entah itu soal penutup wajah atau yang lainnya. Ini tegas dikatakan Sarah: “Jika tujuan memakai penutup wajah adalah menjaga kehormatan, penutup yang hakiki adalah hargai diri dan rasa malu seorang wanita, bukan selembar kain. Inilah yang selalu diucapkan Sarah kepada keluarganya. Mereka tidak paham akan ucapan ini, termasuk Sarah sendiri. Tidak ada hubungan antara kehormatan wanita dan penutup wajah. Masalah ini hanya tradisi, tidak lebih"(Hani Naqshabandi, 2010:11). Jelas, Sarah mengkritik tradisi dimana seharusnya cadar sebagai simbol kehormatan malah dirusak oleh kebejatan kaum laki-laki dan perempuan sebagai kaum rendahan. Karena itu, isi kritiknya ialah bahwa aturan yang dianut oleh keluarganya dan suaminya tidak berhubungan dengan prinsip agama dan syariat, entah itu soal penutup wajah atau yang lainnya. 2) Masalah Pernikahan Dini, Sarah menikah muda dan terlambat memiliki anak. Sarah lahir dari keturunan Saudi, dan mempunyai anak kembar, tetapi anaknya lahir terlambat dari usia pernikahannya. Sarah memiliki paras cantik, dalam kecantikannya sering terjadi pemberontaka dalam dirinya sehingga gampang menyerah. Buktinya jelas bahwa "Sarah lahir dari sebuah keluarga Saudi yang Konservatif. Ia menikah muda dan mendapatkan anak kembar yang lahir agak terlambat jika dilihat dari usia pernikahannya. Sarah wanita cantik yang berkulit kemerahan, bertubuh sangat menarik, bermata jeli, dan berambut panjang. Kecantikan yang layak melahirkan pemberontakan untuk mendapatkannya. Namun, pemilik kecantikan itu tidak mampu memberontak. Setiap kali berontak terhadap diri sendiri ia kalah dan menyerah. Hanya sesekali dia mengalami kemenangan”. (Hani Naqshabandi, 2010:10). 3) Pasangan Hidup, Sarah memiliki masalah pada suaminya yang sebenarnya tidak mencintainya. Sarah tidak memperdulikan suaminya lagi karena suaminya tidak pernah memperdulikan Sarah. Sang suami hanya memperdulikan sarah ketika ingin memuaskan hasrat seksualnya. Teks Novel menyatakan: "Ia tidak terlalu memikirkan suaminya. Ia tidak tahu apakah sang suami masih tidur, seperti ketika ia ditinggalkan, atau telah pergi. Sang suami ada di rumah atau tidak di rumah sama saja bagi Sarah. Sarah berpikir, bagaimana mungkin para lelaki tidak menyadari kebencian seorang perempuan yang mendapatkan kebebasan dari suaminya yang tidak peduli: kapan ia pergi dan kapan ia kembali. Kepedulian suami ketika hasrat seksual minta dipuaskan”. Hani Naqshabandi 
(2010:16). Ternyata Khalid, suaminya tidak memperlakukan Sarah sebagai seorang manusia yang sebenarnya memiliki kehormatan diri dan memiliki nilai kemanusiaan.

\section{Maksud Pengarang Perempuan pada Novel Perempuan Terpasung: Gejolak Cinta di Balik Cadar, Karya Hani Naqshbandi \\ Maksud Pengarang novel Perempuan Terpasung: Gejolak Cinta di Balik Cadar} mengisahkan tentang seorang wanita Arab Saudi bernama Sarah yang membuat mata terbuka lebar akan kehidupan para wanita di negri Timur Tengah. Kehidupan yang ternyata jauh dari nilai baik dari sudut pandang Islam. Wanita yang seharusnya dimuliakan dan dilindungi serta dijaga kehormatannya oleh seorang suami, ternyata tidak lebih dari sekedar pelengkap dan pemanis isi rumah serta pemuas syahwat semata. Sarah, wanita muslim dari Arab Saudi, istri dari seorang Khalid dan juga merupakan ibu dari dua orang anak. Ia hidup dalam kungkungan tradisi kolot yang berkedokkan agama. Sarah yang setiap harinya tersiksa oleh kesendirian menjadi seorang istri dan ibu tanpa bantuan seorangpun. Pengarang juga menggambarkan penghianatan keluarga yang sebenarnya bukanlah kebiasaan masyarakat muslim.

\section{Nilai-nilai Novel Perempuan Terpasung: Gejolak Cinta di Balik Cadar, Karya Hani Naqshbandi}

Novel perempuan Terpasung: Gejolak Cinta di Balik Cadar mengandung nilainilai 1) Nilai Agama, tokoh-tokoh dalam novel menampilkan agama Muslim, walaupun sebagian dari anggota keluarga tidak mengamalkan agama, seperti Khalid, suami Sarah. Sarah, menginginkan bahwa tidak baik hidup hanya berkedok agama padahal agama seharusnya dijadikan sebagai tuntunan dalam sikap dan perilaku. 2) Moral yaitu Nilai Tanggung Jawab, sikap tanggungjawab yang dilakukan Sarah terkait dengan penggunaan penutup wajah (Cadar) yang idealnya dijadikan simbol kehormatan sebagai seorang perempuan Saudi. Sarah konsisten dan paham bahwa penggunaan cadar sebagai tanda bahwa wanita layak dihormati bukan disiksa kemudian menjadi korban kaum lelaki. Selain itu, nilai Taat Aturan/Tradisi, Sarah tidaklah melakukan konfrontasi dan kekekarasan terhadap aturan pemakaian cadar dan tidak melakukan perlawanan atas situasi yang dihadapinya sekalipun ia merasa bahwa dirinya dan teman-temannya kurang dihargai martabatnya sebagai perempuan bahkan dianggap sebagai kaum 
rendahan. 2) Nilai Pengajaran, tokoh perempuan dalam novel mengajarkan kepada semua pembaca agar mendobrak opini perempuan sebagai manusia kelas dua sebab perempuan memiliki banyak potensi. Sarah telah melakukannya dengan cara menuangkan sekaligus menyuarakan permasalahan perempuan berdasarkan tulisantulisannya yang dimuat di surat kabar di London. 4) Nilai Keluarga, keluarga yang harmonis adalah keluarga yang diidamkan Sarah, namun yang terjadi sebaliknya. Keluarga yang utuh adalah tanda keluarga bahagia. Novel ini memberikan pengajaran kepada pembaca agar saling menghormati dan setia antar anggota keluarga.

\section{Simpulan dan Saran}

Kajian feminis dalam novel Perempuan Terpasung: Gejolak Cinta di Balik Cadar terdiri atas karakteristik tokoh perempuan yaitu sabar, baik hati, penyendiri, penurut, pemberontak, dan bijaksana. Selain itu, kedudukan, peran dan fungsi perempuan ialah sebagai seorang isteri bagi suami dan ibu bagi anak-anak, berkedudukan sebagai anak terakhir dalam keluarganya serta seorang penulis di surat kabar. Selanjutnya, permasalahan yang dihadapi tokoh perempuan ialah permasalahan tradisi/budaya, pernikahan dini dan masalah pasangan hidupnya yang tidak peduli. Seterusnya, novel ini ditulis pengarang dengan maksud menampilkan permasalahan yang mayoritas dialami oleh semua perempuan diberbagai negara termasuk Saudi, asal negara Sarah dimana yang mengalami penderitaan karena tindakan suami/laki-laki yang kurang menghormati perempuan. Akhirnya, nilai-nilai yang terkandung dalam novel ialah nilai agama, moral, pengajaran dan nilai keluarga.

Berdasarkan hasil-hasil penelitian maka peneliti memberikan beberapa saran, antara lain 1) agar banyak kajian/penelitian feminis dilakukan untuk mengungkapkan kesetaraan antara laki-laki dan perempuan, 2) agar semakin banyak penulis perempuan dalam menciptakan karya sastra sehingga kehidupan masyarakat khususnya kaum feminis dapat ditampilkan ke permukaan sebagai tokoh andalan dan bukan kaum rendahan. 3) agar melalui kajian feminisme dapat membuka mata kaum perempuan untuk memperjuangkan hidupnya demi mencapai kesetaraan antara laki-laki dan perempuan. 4) agar para peneliti banyak melakukan kajian tentang feminis untuk meningkatkan derajat keperempuanan perempuan. 


\section{DAFTAR PUSTAKA}

Aning Ayu Kusumawati. 2013. Feminisme Islam Dalam Novel El Khalieqy, 14 (2), 116. http://ejournal.uin-suka.ac.id.

Bambang Aris Kartika, 2011. Deskriptif Male Feminisme Dan Kontra Male Feminisme perilaku Tokoh Priyayi Golongan Ningrat jawa dalam Novel Poskolonial Indonesia, $1(2), 237$. https://jurnal.unej.ac.id.

Dani Hermawan, Shandi. 2019. Pemanfaatan Hasil analisis Novel Seruni Karya Sufeeya Sebagai Bahan ajar sastra di SMA, 12 (1), 12. http://ejournal.unibba.ac.id.

Elvi Novrita Putri, dkk. 2019. Feminisme dalam novel Saman karya Ayu Utami Dan implementasinya dalam Pembelajaran teks novel kelas XII SMA, 8 (3), 94. https://ejournal.unp.ac.id

Indrya Mulyaningsih, Iain Syekh Nurjati, 2015. Kajian Feminisme Pada Novel Ronggeng Dukuh Paruk Dan perempuan Berkalung Sorban, 1 (1), 109. https://.uncp.ac.id

Moleong. Lexy J. 2012. Metodelogi Penelitian Kualitatif. Bandung: Remaja Rosdakarya

Nyoman Kutha Ratna, S.U. 2004. Teori, Metode, Dan Teknik Penelitian Sastra. Yogyakarta: Pustaka Pelajar.

Tia Ratna Zuraida, dkk. 2013. Pemberontakan Perempuan Dalam Novel Perempuan badai Karya Mustofa Wahid Hasyim: Kajian Feminisme, 3 https://journal.unnes.ac.id.

Yenni Hayati, 2012. Dunia Perempuan Dalam Karya Sastra Perempuan Indonesia (Kajian Feminisme ), 11 (1), 85. https://ejournal.unp.ac.id

Yuningsih, dkk. 2015. Feminisme Dalam Novel Perempuan Berkalung Sorban Karya Abidah El Khalieqy Dan kelayakannya, 2. http://jurnal.fkip.unila.ac.id. 